\title{
WYBRANA TWÓRCZOŚĆ PIŚMIENNICZA ARCHITEKTÓW ZWIĄZANYCH Z POLITECHNIKĄ LWOWSKĄ. STUDIUM NA PODSTAWIE BADAŃ ZBIORÓW BIBLIOTEKI POLITECHNIKI KRAKOWSKIEJ SPRZED 1945 ROKU
}

Słowa kluczowe: architekci, piśmiennictwo architektoniczne, Politechnika Lwowska, księgozbiór Biblioteki Politechniki Krakowskiej, XIX/XX wiek

Politechnika Lwowska', zwana ,matką polskich politechnik”, miała znaczący wpływ na powstanie i kształt innych polskich uczelni technicznych. Jej wkład w rozwój nauk technicznych oraz w kształcenie przyszłej kadry naukowej jest niezwykle istotny. Podejmowane przez Bibliotekę Politechniki Krakowskiej (dalej: BPK), jak również inne jednostki uczelni działania² mają na celu podkreślenie

${ }^{1}$ Lwowska uczelnia techniczna posiada długą i zawiłą historię, w czasie której zmieniała swój kształt organizacyjny, w tym kilkukrotnie swoją nazwę. W źródłach omawiających historię Politechniki Lwowskiej można znaleźć odmienne daty graniczne. Za początek wyższej szkoły technicznej uznaje się powszechnie rok 1844, kiedy to z nadania cesarza Ferdynanda I wcześniejsza Szkoła Realna (1817-1844) przyjęła nazwę C.K. Akademia Techniczna (1844-1877) i została podniesiona do rangi szkoły wyższej. W 1877 r. została ona przekształcona w C.K. Szkołę Politechniczną (1877-1921). Powszechnie stosowaną nazwę (również obecnie) - Politechnika Lwowska uczelnia otrzymała w $1921 \mathrm{r}$. i funkcjonowała pod nią do 1939 r., kiedy to pod okupacją sowiecką została przekształcona w Lwowski Instytut Politechniczny. Po zakończeniu II wojny światowej, już poza granicami Polski, uczelnia nadal funkcjonowała pod nazwą Lwowski Instytut Politechniczny. Obecna nazwa - Uniwersytet Narodowy Politechnika Lwowska - została nadana uczelni w 2000 r. Jak już wcześniej wspomniano, to właśnie nazwa Politechnika Lwowska jest najbardziej uniwersalna i głęboko zakorzeniona w historii i świadomości pokoleń. Dlatego też autorki w tekście posługują się głównie tą nazwą, niezależnie od nazwy funkcjonującej w danym okresie działalności uczelni. Zob.: Politechnika Lwowska: 1844-1945, kom. red. J. Boberski et al., Wrocław 1993; J. Piłatowicz, Politechnika Lwowska w dwudziestoleciu międzywojennym, „Kwartalnik Historii Nauki i Techniki”, t. 36, 1991, nr 1, s. 25-70; J. Szymczyk, O fenomenie Politechniki Lwowskiejmatki polskich politechnik w 160-lecie jej powstania (1844-2004), „Energetyka”, 2004, nr 12, s. $762-769$.

${ }^{2}$ Kolekcja Lwowiana, wyodrębniona w latach 2013-2014 z najstarszego księgozbioru BPK, w skład której wchodzą druki do 1945 r. wydane we Lwowie oraz dotyczące Lwowa; wystawa 
wspólnych korzeni oraz zachowanie i popularyzację dziedzictwa lwowskiej spuścizny z zakresu nauk technicznych.

Dokonania kadry i absolwentów Politechniki Lwowskiej (dalej: PL) z zakresu różnych dziedzin wiedzy są wyjątkowo bogate i posiadają trwałą wartość naukową. Środowisko architektoniczne jest jednym z lepszych tego przykładów. Zawiłe dzieje Wydziału Architektonicznego PL nie stanowią przedmiotu niniejszego opracowania, informacje na jego temat zostały zebrane i szczegółowo scharakteryzowane między innymi w pracy Zbysława Popławskiego Politechnika Lwowska w latach 1844-1945: rodowody katedr, wykaz nauczycieli akademickich, dziedzictwo (Kraków 1999). Należy jednak pamiętać, że wydział ten nie zawsze funkcjonował samodzielnie ${ }^{3}$, a liczne zmiany doprowadziły ostatecznie do przemianowania Wydziału Budownictwa na Wydział Architektoniczny dopiero w $1894 \mathrm{r}$.

Naturalne jest, że osiagnięcia architektów najbardziej widoczne są na przykładzie budynków i obiektów, których są autorami i które mamy możliwość podziwiać do dzisiaj. Wielu z tych architektów prowadziło jednak również działalność naukowo-dydaktyczną, której rezultatem są między innymi liczne opracowania teoretyczne.

Aby podjąć prace nad zagadnieniem, w pierwszej kolejności konieczne było sporządzenie wykazu architektów, którzy w jakikolwiek sposób byli powiązani z PL (kadra naukowa, absolwenci i studenci). Pomocnym źródłem przy tworzeniu tego zestawienia okazały się trzy opracowania: Album inżynierów i techników w Polsce (Lwów 1932) oraz dwie prace Stanisława Łozy: Stownik architektów i budowniczych Polaków oraz cudzoziemców w Polsce pracujacych (Warszawa 1930, wyd. 2), Architekci i budowniczowie w Polsce (Warszawa 1954). Bogatym zasobem wiedzy okazał się również serwis internetowy In memoriam - Pamięci Architektów Polskich, prowadzony pod patronatem Izby Architektów Rzeczypospolitej Polskiej oraz Stowarzyszenia Architektów Polskich. Dzięki sporządzonemu wykazowi możliwe było przeprowadzenie analizy najstarszej części księgozbioru BPK, w efekcie której wyselekcjonowano prace architektów związanych z PL.

zorganizowana przez BPK oraz wydany przy tej okazji katalog Leopolis semper Fidelis (Kraków 2015); publikacja opracowana przez Muzeum PK pod tytułem Dziedzictwo akademickiego Lwowa na Politechnice Krakowskiej (Kraków 2017); projekt Bibliotek PK i AGH (Europejskie Dziedzictwo Techniczne), w którym zawarto również kolekcję Lwowiana.

${ }^{3}$ Wykłady z zakresu architektury funkcjonowały już w czasach C.K. Akademii Technicznej (w ramach Szkoły budownictwa), natomiast odrębne katedry rysunku ornamentalnego i modelowania powstały w roku akademickim 1873/1874. W 1877 r. Akademii Technicznej nadano status Szkoły Politechnicznej, utworzono wtedy m.in. Wydział Budownictwa, na którym obok przedmiotów z budownictwa lądowego i mechaniki budowlanej wykładano również przedmioty z zakresu architektury. Obejmowały one naukę form architektonicznych, historię architektury oraz rysunek ornamentalny i modelowanie. Zob. Program C.K. Akademii Technicznej Lwowskiej: na rok naukowy 1873/4, Lwów 1873; Program Ces. Król. Szkoły Politechnicznej we Lwowie: na rok naukowy 1878/79, Lwów 1878. 
Rok 1945 został przyjęty jako data graniczna podstawy badań, w związku z czym tutaj omówiono wyłącznie opracowania opublikowane przed tym rokiem ${ }^{4}$. Wiąże się to z tym, że w BPK mianem najstarszego księgozbioru określa się książki wydane do 1945 r., jest to również data powstania krakowskiej politechniki.

Celem niniejszej publikacji jest zwrócenie uwagi na wartość naukową i historyczną dorobku piśmienniczego architektów powiązanych z lwowską uczelnią na podstawie egzemplarzy posiadanych w zbiorach BPK. Przytoczono wybrane fakty z życiorysów prezentowanych twórców, jednak stanowią one jedynie tło rozważań. Ze względu na obszerny materiał źródłowy omówiono prace jedenastu wybranych architektów ${ }^{5}$.

\section{ARCHITEKCI Z KOŃCA XIX W.}

Wśród prac najstarszego pokolenia profesorów PL w zbiorach BPK znajdują się opracowania polskiego architekta niemieckiego pochodzenia Gustawa Bisanza (1848-1925). Był on uczniem Juliana Zachariewicza, z którym później współpracował przy projektowaniu nowego budynku politechniki oraz dalszej jego rozbudowy. Bisanz przez niemal całe życie związany był z PL, gdzie na przestrzeni lat sprawował między innymi funkcje prodziekana i dziekana na Wydziale Architektonicznym ${ }^{6}$ oraz dwukrotnie piastował stanowisko rektora PL (1888/1889 i 1898/1899). Bisanz był członkiem komisji egzaminacyjnych podczas egzaminów państwowych oraz wielokrotnie zasiadał w jury konkursów architektonicznych. Miał on znaczący udział w kształtowaniu profilu naukowego uczelni oraz wychowywaniu młodego pokolenia architektów i inżynierów.

W zbiorach BPK znajdziemy dwa wydania dwutomowego podręcznika Budownictwo (Lwów 1908 i 1909)7, które zostały opracowane na podstawie wykładów Bisanza przez jego studenta Adolfa Eisensteina i opatrzone rysunkami Ignacego Barbera ${ }^{8}$. Wszystkie edycje tego podręcznika są odbitkami litograficznymi pisma ręcznego, wzbogacone są licznymi rysunkami ilustrującymi

${ }^{4}$ Część z omawianych osób kontynuowała swą działalność piśmienniczą również po zakończeniu II wojny światowej. W naszych zbiorach są też książki ich autorstwa wydane po $1945 \mathrm{r}$.

${ }^{5} \mathrm{~W}$ księgozbiorze BPK można odnaleźć również publikacje innych architektów związanych z PL, m.in. Kazimierza Mokłowskiego (1869-1905), Kazimierza Bartoszewicza (1886-1945), Henryka Jasieńskiego (1888-1967), Emila Łazoryka (1897-1945), Bogdana Laszczki (1898-1977), Jana Ekielskiego (1902-1942) czy Stefana Świszczowskiego (1903-1989).

${ }^{6}$ Bisanz był dziekanem na Wydziale Budownictwa w latach 1883-1889. Następnie - po przekształceniu Wydziału Budownictwa w Wydział Architektoniczny - pełnił funkcję dziekana tegoż Wydziału jeszcze w latach 1895-1898 i 1901-1903.

7 BPK, sygn. III-17334, IV-300934, IV-300935 (kolekcja: Lwowiana).

8 Jest to kolejne opracowanie wykładów Profesora, pierwsze - najbardziej znane - opatrzone jest datami 1893-1898 i zostało sporządzone przez grupę studentów: Kazimierza Teodorowicza, Alfreda Zachariewicza, Artura Kühnela, Tadeusza Obmińskiego i Mieczysława Teodorowicza. 
zagadnienia omawiane w tekście i uzupełnione jedenastoma rozkładanymi tablicami. Całość dzieła jest cennym zbiorem wiedzy na temat sztuki budownictwa opartej na najlepszych wzorcach i pozostaje do dziś wartościowym i pomocnym źródłem na przykład podczas prac restauracyjnych zabytkowych obiektów ${ }^{9}$. Znajdziemy tu między innymi informacje na temat najpopularniejszych wówczas materiałów stosowanych $\mathrm{w}$ budownictwie, technik wznoszenia różnego typu konstrukcji oraz opisy poszczególnych elementów budowlanych.

W księgozbiorze BPK nie zabrakło prac jednego z najwybitniejszych polskich architektów i teoretyków architektury przełomu XIX i XX w. - Jana Sas-Zubrzyckiego (1860-1935). Architekturę na lwowskiej uczelni studiował w latach 1878-1884, a później był jej profesorem i pierwszym w niepodległej Polsce dziekanem Wydziału Architektonicznego. Sas-Zubrzycki był autorem wielu książek i artykułów z zakresu historii architektury i sztuki, filozofii architektury, podejmował także rozważania na temat polskiego stylu narodowego oraz sztuki ludowej. Działalności teoretycznej i piśmienniczej Sas-Zubrzyckiego towarzyszyły liczne prace projektowe i renowacyjne obiektów sakralnych, budynków użyteczności publicznej, willi i kamienic. Za najważniejszą część jego artystycznego dorobku należy jednak uznać kościoły, których zaprojektował lub zmodernizował około sześćdziesięciu. Wśród nich warto wymienić kościoły w Szczurowej, Porębie Radlnej, Tarnowie czy Jordanowie oraz krakowskie kościoły - św. Józefa w Podgórzu i redemptorystów przy ulicy Zamojskiego.

Liczne prace Sas-Zubrzyckiego, które znajdują się w zbiorach BPK, omówiono w podziale na cztery grupy tematyczne: I. Dzieła Rękodzielnictwa polskiego; II. Dzieła architektoniczne; III. Dzieła z zakresu Sztuki i Oświecenia; IV. Cztery dzieła, obejmujące pierwiastki sztuki polskiej ${ }^{10}$. Z pierwszej grupy publikacji architekta posiadamy opracowanie Murarz polski: wzory i przyklady polskiego budownictwa ceglanego (Lwów 1919) ${ }^{11}$. Pracę tworzy pięć zeszytów z lat 1917-1919, w których znajdują się ilustracje różnych rozwiązań konstrukcyjnych oraz detali architektonicznych stosowanych w budownictwie murowanym wraz z ich krótkim omówieniem.

Najliczniejszą grupę publikacji stanowią rozprawy dotyczące poszczególnych dzieł architektonicznych. Godne uwagi jest obszerne studium Krakowska Szkoła Architektoniczna XIV wieku: studium krytyczne (Kraków 1902) ${ }^{12}$, które ukazało się w „Roczniku Krakowskim” i zostało oparte na wykładzie habilitacyjnym wygłoszonym w 1895 r. na PL $^{13}$. O pracy tej wspomniano w ówczesnej

${ }^{9}$ W 2017 r. ukazał się reprint tegoż dzieła: G. Bisanz, Budownictwo, Katowice 2017.

${ }_{10}$ Taki podział tematyczny opracowań Sas-Zubrzyckiego znajduje się w ostatnim zeszycie publikacji Cieślictwo polskie: uzupetnienie Polskiego budownictwa drewnianego: z rysunkami, z. 3, Lwów 1930, s. 211.

${ }^{11}$ BPK, sygn. III-15166, III-28850 (kolekcja: Lwowiana).

12 BPK, sygn. III-15145 (kolekcja: Cracoviana).

13 Tytuł wygłoszonego 28 stycznia 1895 r. referatu habilitacyjnego Sas-Zubrzyckiego brzmiał Rozwój gotycyzmu w Polsce pod względem konstrukcyjnym i estetycznym. 
prasie, że jest „arcyspecyalna i dla znawców fachowych tylko dostępna [...], starająca się udowodnić istnienie samoistnego stylu w budowie niektórych kościołów, stylu, różnego od niemieckiego i francuskiego"14. Kolejne prace Sas-Zubrzycki opublikował w „Sprawozdaniach Komisyi do Badania Historyi Sztuki w Polsce"15, są to: Miasto Jarostaw i jego zabytki (Kraków 1903) ${ }^{16}$, Kościót warowny w Bóbrce (Kraków 1905) ${ }^{17}$ oraz Rohatyn miasto Królewskie (Kraków $1913)^{18}$. W obrębie tej grupy tematycznej znajdują się także wydawnictwa samoistne autorstwa Sas-Zubrzyckiego. W zbiorach BPK można odnaleźć dwa opracowania dotyczace krakowskiej przestrzeni miejskiej: Architektura Placu Dominikańskiego w Krakowie na poczatku XIX wieku (Kraków 1908) ${ }^{19}$ oraz Architektura Rynku Krakowskiego z czasów Królestwa Polskiego (Kraków 1909)20. Kolejne to: Styl nadwiślański jako odcień sztuki średniowiecznej w Polsce (Kraków 1910) ${ }^{21}$ i Styl zygmuntowski (Kraków 1910) ${ }^{22}$, których celem było „udowodnienie istnienia odrębnego stylu w architekturze polskiej, a co za tym idzie - dojrzałości i wyjątkowości kultury polskiej”23. Biblioteka PK posiada również monumentalne dzieło Sas-Zubrzyckiego Skarb architektury w Polsce (Kraków 1907-1916) ${ }^{24}$, obejmujące czterysta kart tablic z ilustracjami, umieszczonych w czterech opasłych tomach. Architekt tak argumentował zasadność opracowania tej publikacji:

${ }^{14}$ Dawny Kraków, „Nowa Reforma” 1899, nr 223, s. 1.

${ }^{15}$ Warto wspomnieć, że Sas-Zubrzycki od 1902 r. był członkiem Komisji Historii Sztuki Akademii Umiejętności w Krakowie, w skład której wchodziło liczne grono lwowskich uczonych. Komisja ta od 1877 r. zaczęła wydawać pierwszy na ziemiach polskich specjalistyczny periodyk z zakresu historii sztuki - „Sprawozdania Komisyi do Badania Historyi Sztuki w Polsce” (po I wojnie światowej pod zmienionym tytułem „Prace Komisji Historii Sztuki”). Na łamach tego czasopisma swoje prace ogłaszali również architekci, wśród nich przywołany w dalszej części tekstu Adolf Szyszko-Bohusz. Zob. A. Bochnak, Zarys dziejów polskiej historii sztuki, Kraków 1948, s. 11-19; A. Małkiewicz, Z dziejów polskiej historii sztuki: studia i szkice, Kraków 2005, s. 19-20.

${ }^{16}$ BPK, sygn. III-18969 (kolekcja: Cracoviana).

17 BPK, sygn. III-18969 (kolekcja: Cracoviana). Część III w rozprawie Kościoły i cmentarze warowne w Polsce przez Maryana Sokołowskiego, Grzegorza Worobjewa i Jana Zubrzyckiego, szp. 481-528.

18 BPK, sygn. III-18969 (kolekcja: Cracoviana).

19 BPK, sygn. III-18881 (kolekcja: Cracoviana).

20 BPK, sygn. III-33236 (kolekcja: Cracoviana).

${ }^{21}$ BPK, sygn. III-17883 (kolekcja: Cracoviana). Interesujący jest fakt, że pierwsza recenzja tego opracowania, która ukazała się na łamach „Architekta”, była krytyczna. Jej autorem był inny ceniony architekt, Adolf Szyszko-Bohusz, który w zakończeniu recenzji w kąśliwy sposób zauważa: „Odczujmyż przecie nareszcie ową polskość, ujawniającą się we wszystkich stylach historycznych na ziemi naszej, a może nie będziemy potrzebowali do życia powoływać jakiegoś zmyślonego «stylu nadwiślańskiego»". Zob. J. Sas-Zubrzycki, Styl nadwiślański jako odcień sztuki średniowiecznej w Polsce, Kraków 1910. Rec.: A. Szyszko-Bohusz, Styl nadwiślański, „Architekt”, R. 11: 1910, z. 9, s. 133.

22 BPK, sygn. III-15029 (kolekcja: Cracoviana).

23 J. Wowczak, Jan Sas-Zubrzycki, Kraków 2017, s. 234.

${ }^{24}$ BPK, sygn. IV-35003 (kolekcja: Cracoviana). 
Od lat wielu gromadzą u nas zabytki, ażeby ze szczątków ich utworzyć obraz sztuki minionej. Czas już wysoki, ażeby przystapić do zbierania ich w grupy i działy dla lepszego przeglądu. [...] Dzieło, złożone ze samych tablic, dokładnie rysy każdego szczegółu oddających, stanie się podręcznikiem tak dla architektów, jak i rzeźbiarzy, wreszcie nawet dla samych miłośników sztuki architektonicznej ${ }^{25}$.

Sas-Zubrzycki w dziele tym umieścił tablice ze zdjęciami, rysunkami i rycinami przedstawiającymi najcenniejsze i najstarsze zabytki architektury polskiej oraz ich najciekawsze detale architektoniczne. O wartości dzieła świadczy fakt, że „księgi te, nie tylko mają tę zaletę, że są liczne, mają prócz tego jeszcze szczęście (o które u nas niełatwo), że wyczerpują się w handlu, lub nawet drukowane są w wydawnictwach wtórnych, uzupełnianych i poprawianych"26. Kolejna książka wydana nakładem autora i opatrzona jego rysunkami to Sklepienia polskie z doby średniowiecza i odrodzenia (Lwów 1926) ${ }^{27}$, w której Zubrzycki po raz kolejny podjął rozważania o znaczeniu polskiej i słowiańskiej architektury w rozwoju architektury europejskiej. W drugiej grupie tematycznej mieści się również Cieślictwo polskie: uzupetnienie Polskiego budownictwa drewnianego: z rysunkami (Lwów 1930) ${ }^{28}$, wydane w trzech zeszytach, stanowiące bogato ilustrowany wzornik z przykładami ojczystych detali drewnianych. W nocie umieszczonej w książce, mającej zachęcić do kupna tego wydawnictwa, możemy przeczytać: „Każdy miłośnik sztuki polskiéj znajdzie w Cieślictwie polskiém kopalnie pierwiastków czysto rodzimych i pięknych, wiecznie żywotnych i godnych rozwoju"29.

Trzecia grupa tematyczna publikacji Sas-Zubrzyckiego dotyczy dzieł z zakresu Sztuki i Oświecenia. W 1901 r. wydał on książkę Żótkiew: studium architektoniczne (Kraków 1901) ${ }^{30}$, która była pierwszą w dorobku piśmienniczym autora monografią miasta. Opierał się w niej na bogatym materiale źródłowym oraz sam wykonał rysunki inwentaryzacyjne zabytków. W tej grupie znajdziemy również trzyczęściowy podręcznik do historii architektury Utwór kształtu: nauka wstępna do znajomości stylów architektonicznych (Cz. 1 - Kraków 1912; Cz. 2 Kraków 1913; Cz. 3, z. 2 - Kraków 1916) ${ }^{31}$. Dzieło to zawiera rozważania dotyczące wcześniejszych poglądów i założeń autora. W „Czasopiśmie Technicznym” znajdziemy informacje o ukazaniu się pierwszej części oraz zapowiedź kolejnych:

25 J. Sas-Zubrzycki, Skarb architektury w Polsce, t. 1, Kraków 1907-1909, s. [3].

26 J. Dziekoński, Księgi o Architekturze d-ra S. Zubrzyckiego, „Przegląd Techniczny”, R. 53: 1915, nr 31-32, s. 321.

${ }^{27}$ BPK, sygn. II-1434 (kolekcja: Lwowiana).

${ }^{28}$ BPK, sygn. III-15114, III-17592, IV-300928, IV-300929 (kolekcja: Lwowiana).

29 J. Sas-Zubrzycki, Cieślictwo polskie: uzupetnienie Polskiego budownictwa drewnianego: z rysunkami, z. 1, Lwów 1930, 2 s. okł.

${ }^{30}$ BPK, sygn. I-30214 (kolekcja: Cracoviana).

${ }^{31}$ BPK, sygn. III-15004, III-15017, III-15136 (kolekcja: Cracoviana). W zbiorach BPK posiadamy wszystkie części tego wydawnictwa. Części druga i trzecia są jednak zdekompletowane (egzemplarze w zbiorach BPK - cz. 2, od początku do s. 48, cz. 3 - tylko zeszyt 2 od s. 145). 
Dzieło obejmie III części, a mianowicie: kształty linijne - kształty na płaszczyźnie i powierzchni, wreszcie kształty w przestrzeni. Jako podręcznik daje pogląd ogólny na zasady utworu kształtowego z punktu widzenia filozoficznego i estetycznego. Gdy literatura polska w ogóle jest bardzo uboga w dzieła architektoniczne, pojawienie się takiej książki powinno obudzić wielkie zaciekawienie, tem więcej, że w podobny sposób opracowana książka nie istnieje zdaje się w literaturze obcej ${ }^{32}$.

Każda z części opatrzona jest licznymi rysunkami i fotografiami, które w znacznej mierze obrazują rodzime elementy i obiekty architektoniczne. Najważniejsze miejsce w tej grupie tematycznej zajmuje Zwięzła historja sztuki: od najpierwszych jej zaczatków aż po czasy napoleońskie (Kraków 1914, wyd. 2 powiększone) $)^{33}$. Autor w tym naukowym opracowaniu starał się ukazać rozwój sztuki światowej z uwzględnieniem historii sztuki polskiej. Pierwsze wydanie ukazało się w 1904 r. i zostało określone „bardzo dobrym przewodnikiem dla pragnących się zapoznać z dziejami sztuki, a nader dogodnym i pouczającym podręcznikiem, dla pracujących na tem polu, podręcznikiem przynoszącym wiele zdrowych uwag, świeżych i oryginalnych poglądów oraz nowych i bystrych spostrzeżeń" ${ }^{34}$. Pracę uzupełniają liczne autorskie ilustracje. W innym swoim dziele, Obsypiny ... obsytania ...: rąbek zloty z czasów dobrobytu i oświaty Polaków dawnych (Kraków-Warszawa 1921) ${ }^{35}$, architekt skupił się na opisie staropolskich zwyczajów oraz starał się udowodnić, że nasza kultura słowiańska jest pierwowzorem dla innych kultur europejskich. BPK w swoich zbiorach posiada również broszurę Dwa zamki polskie w Malborku: w rocznicę dziesiata odzyskania Pomorza (Lwów 1930) ${ }^{36}$, w której ponownie Sas-Zubrzycki stara się dowieść odrębności i wyższości słowiańskiej kultury i tradycji budowlanej nad niemiecką cywilizacją. Autor swoją tezę popiera licznymi przykładami elementów i detali architektonicznych znajdujących się w malborskim zamku, a wywodzących się z kultury dawnych Słowian. Dodatkowo druk ten wzbogacony jest czterdziestoma odręcznymi rysunkami Sas-Zubrzyckiego.

Ostatnia grupa prac Sas-Zubrzyckiego obejmuje cztery dzieła opisujące pierwiastki sztuki polskiej. W zbiorach BPK znajdziemy trzy z nich: Serce: rozbiór

32 J. Sas-Zubrzycki, Utwór ksztaltu: nauka wstępna do znajomości stylów architektonicznych, cz. 1, Kraków 1912. Rec.: Recenzye i krytyki. Dr. Jan Zubrzycki, Utwór ksztattu, „Czasopismo Techniczne", R. 30: 1912, nr 33, s. 434.

${ }_{33}$ BPK, sygn. II-15024. Pierwsze wydanie tej pracy pochodzi z 1904 r. i składa się z trzech części (sztuka starożytna, średniowieczna i nowożytna). Posiadane przez nas drugie wydanie tegoż dzieła obejmuje dwie części (sztuka starożytna oraz sztuka starochrześcijańska i średniowieczna), w informacji podanej przez wydawcę czytamy natomiast, że druk części trzeciej z powodu wybuchu wojny został opóźniony.

${ }^{34}$ Bibliografia. Dr. J. S. Zubrzycki: „Zwięzła historja sztuki uwzględniajaca szczególnie historj sztuki w Polsce, z określeniem znamion rodzimej sztuki romańskiej, gotyckiej i odrodzenia". Kraków 1904, „Architekt” 1905, z. 5, s. 75-80.

35 BPK, sygn. II-29397 (kolekcja: Lwowiana).

36 BPK, sygn. II-21439, II-28706, II-328045 (kolekcja: Lwowiana). 
pierwiastków polskiej sztuki ludowej i narodowej (z rysunkami) (Lwów 1921) ${ }^{37}$; Styl polski, styl narodowy (Lwów 1922) ${ }^{38}$ oraz Mir - sława: znak krzyżowy: rozbiór najdawniejszego pierwiastka architektonicznego (Lwów 1922)39.

Wyjątkowe miejsce wśród zbiorów BPK znajduje projekt architektoniczny wykonany przez Sas-Zubrzyckiego, opatrzony tytułem Pomyst kościoła w Porębie Radlnej (Kraków 1903) ${ }^{40}$. Jest to sześć oryginalnych, wielkoformatowych tablic przedstawiających barwne rysunki konturowe wykonane tuszem, a następnie lawowane akwarelą. Prezentują one kolejno rzut poziomy kościoła, jego przekrój poprzeczny, widok przedni, widok boczny, widok absydy i przekrój podłużny. Na każdej z tablic widnieje odręczny podpis architekta oraz dwie wersje jego pieczątki. Ponadto na pierwszej tablicy znajdują się również podpisy: ówczesnego proboszcza w Porębie Radlnej - ks. Ignacego Poniewskiego, dwóch budowniczych z pobliskiej miejscowości Ryglice: Franciszka Wieja (majstra murarskiego) i Franciszka Boratyńskiego ${ }^{41}$, a także trzy nazwiska (najprawdopodobniej członków rady parafialnej bądź komitetu budowy kościoła).

Twórczość Jana Sas-Zubrzyckiego do dzisiaj wyróżnia się indywidualnością i nosi znamiona ściśle określonych przez niego dwóch stylów - nadwiślańskiego i zygmuntowskiego. Architekt cieszył się dużym uznaniem środowiska naukowego, a potwierdzeniem tego mogą być słowa prof. Ottona Nadolskiego, że ten ,zasłużony em. profesor zwyczajny architektury, który swojemi pracami odkrywczemi i popularyzacyjnymi rozbudził umiłowanie dzieł architektonicznych naszej przeszłości, projektami swojego pomysłu zapisał się w szeregach najwybitniejszych polskich architektów"42.

Ciekawą pozycją, którą znajdziemy w zbiorach BPK, jest katalog firmy Józefa Sosnowskiego i Alfreda Zachariewicza ${ }^{43}$. Spółka ta została założona w 1903 r. pod nazwą „Pierwsze Krajowe Przedsiębiorstwo Robót Żelazobetonowych" i była pierwszą w Polsce, która wdrożyła na wielką skalę technologię

37 BPK, sygn. II-1588, II-6275 (kolekcja: Lwowiana).

38 BPK, sygn. II-31979 (kolekcja: Lwowiana).

39 BPK, sygn. II-1587, II-6437 (kolekcja: Lwowiana).

${ }^{40}$ BPK, sygn. G-2549 (kolekcja: Cracoviana).

${ }^{41}$ Sas-Zubrzycki współpracował $\mathrm{z}$ nimi również przy budowie kościoła w Ryglicach i Ciężkowicach. Zob. Parafia św. Katarzyny PM w Ryglicach. Historia kościoła. Krótki rys historyczny, https://ryglice-wiz.diecezja.tarnow.pl/\#parafia (dostęp: 13.02.2020); M. Drogoś, Dzieje kościoła parafialnego pod wezwaniem św. Andrzeja w Ciężkowicach. Historia obrazu Pana Jezusa Miłosiernego, http://www.encyklopedia.ciezkowice.pl/pl/haslo,120,00134,inne (dostęp: 16.04.2020).

${ }^{42}$ O. Nadolski, Przemówienie inauguracyjne J.M. Rektora Politechniki Lwowskiej, Prof. Dr. Inż. Ottona Nadolskiego na uroczystości Inauguracji Roku Akademickiego 1935/36, w dniu 7 października 1935 r., „Czasopismo Techniczne”, R. 53: 1935, nr 20, s. 359.

${ }_{43}$ BPK, sygn. III-16568 (kolekcja: Lwowiana) - katalog opracowany pod tytułem J. Sosnowski i A. Zachariewicz. 
żelbetowych konstrukcji w systemie Hennebique'a ${ }^{44}$. W ciagu dziesięciu lat działalności odegrała znaczącą rolę w budowie przeszło 250 mostów żelbetowych, ponadto wykonała liczne konstrukcje lądowe i wodne. Należy przytoczyć kilka faktów z życiorysów obydwóch założycieli firmy. Pierwszy z nich, Józef Sosnowski (1865-1940), studiował w Kijowie i Odessie. Studia ukończył ostatecznie na PL w 1895 r., gdzie również przez rok pracował jako asystent w Katedrze Budownictwa Lądowego. Jako młody architekt podjął współpracę ze znanym we Lwowie architektem Janem Lewińskim (1851-1919), gdzie również pracował inny początkujący architekt - Alfred Zachariewicz (18711937) ${ }^{45}$. Zachariewicz w latach 1890-1894 studiował na Wydziale Budowlanym PL, a następnie naukę kontynuował na wiedeńskiej politechnice. Po powrocie do Lwowa przez trzy lata pracował na PL. W 1903 r. Sosnowski i Zachariewicz usamodzielnili się i założyli spółkę „J. Sosnowski \& A. Zachariewicz”, którą reklamowali jako „pierwsze krajowe przedsiębiorstwo i fabryka zupełnie ogniotrwałych robót żelazno-betonowych i cementowych"46. To wydarzenie Sosnowski w spisanym przez siebie życiorysie tak wspominał:

Po ukończeniu dworca głównego w roku 1903 zawiązałem spółkę budowlaną z architektem-inżynierem Zachariewiczem i spółka nasza wykonała cały szereg budowli lądowych i wodnych, czego dowodem służy załączony katalog naszej dziesięcioletniej pracy, wydany przed wojną, a który obejmuje tylko roboty żel-betonowe, budowle zaś gdzie nie był zastosowany system żel-betonowy, nie zostały umieszczone w tym katalogu ${ }^{47}$.

Mowa tu właśnie o wspomnianym wcześniej katalogu, który został wydany przez nich dziesięć lat po założeniu wspólnego przedsiębiorstwa. Prezentują w nim w pierwszej kolejności liczne fotografie konstrukcji swojego autorstwa w podziale na pięć kategorii: Mosty; Fabryki; Stajnie; Budynki publiczne i prywatne; Kościoły, grobowce, klasztory - w których wykonano roboty żelazno-betonowe. W dalszej części katalogu znajdują się szczegółowe wykazy z danymi technicznymi wykonanych przez ich firmę różnych elementów konstrukcyjnych. Na posiadanym przez BPK egzemplarzu widnieją odręczne adnotacje z aktualnymi na daną chwilę adresami firmy.

Absolwentem architektury na PL, o którym warto wspomnieć, jest Karol Iwanicki (1870-194148; studia ukończył w 1894 r.). Na początku XX w. był jednym z bardziej cenionych architektów, wykonał liczne projekty obiektów

${ }^{44}$ W 1892 r. francuski inżynier François Hennebique (1842-1921) opatentował innowacyjny na ówczesne czasy system konstrukcji żelbetowej - niezwykle trwałe połączenie stali i betonu.

45 Alfred Zachariewicz był synem wybitnego lwowskiego architekta - Juliana Zachariewicza (1837-1898), talentem dorównał on ojcu.

${ }^{46}$ Krakowska Księga Adresowa: na rok 1907, red. J. Knapik, Kraków 1906, s. 293; Reklama spółki „J. Sosnowski \& A. Zachariewicz” zamieszczona na łamach czasopisma „Architekt” 1903, z. 1.

47 „Curriculum vitae inżyniera - architekty Józefa Sosnowskiego” [maszynopis]. Materiał otrzymany z redakcji Polskiego słownika biograficznego IH PAN.

48 Data śmierci za: Katalog Biblioteki Narodowej. Niektóre źródła podają rok 1940. 
użyteczności publicznej, budynków prywatnych oraz przemysłowych. Ponadto interesował się historią sztuki polskiej i architektury, w rezultacie publikując kilka prac naukowych z tej tematyki. Wartościową pozycją jest jego opracowanie Budownictwo wiejskie: poradnik przy wznoszeniu zabudowań na wsi (Kijów 1917) ${ }^{49}$, które przyniosło mu uznanie w środowisku architektoniczno-budowlanym. W tamtym czasie poradnik ten był niezwykle popularny i pomimo wydania go w okresie I wojny światowej jego nakład został szybko wyczerpany ${ }^{50}$. Jak sam autor napisał we wstępie: „Myślą przewodnią niniejszego dziełka jest chęć ułatwienia wznoszenia budynków wiejskich, możebnie prawidłowo pod względem zasad budownictwa i hygieny, przy zastosowaniu najracjonalniejszej oszczędności" ${ }^{51}$. Poradnik ten miał być pomocny przy samodzielnym wznoszeniu zabudowań wiejskich, bez korzystania z pomocy zawodowców. Iwanicki skupia się w nim na niezbędnych praktycznych informacjach, nie poświęca zbyt wiele uwagi skomplikowanym obliczeniom matematycznym. Autor również wyraża nadzieję, że jego opracowanie stanie się inspiracją do powstania kolejnych tego typu prac, bo - co jak sam zauważa - ówczesne piśmiennictwo zawodowe opisujące „praktyczną samodzielność we wszelkich dziedzinach pracy”52 jest nieliczne i wymaga dalszego rozwoju. Tekst główny uzupełniony jest licznymi tablicami porównawczymi zawierającymi niezbędne i najczęściej stosowane miary i wagi przydatne w budownictwie. Dodatkowo Iwanicki zamieścił w swojej książce przeszło trzydzieści zdjęć - „dla łatwiejszego wyrobienia sobie gustu i żądań od przyszłej swej siedziby, załączamy cały szereg zdjęć z naszych dawnych siedzib, dworów i dworków, tych, co to tyle wspomnień o świetnej naszej przeszłości przechowały, nosząc na sobie zarazem piętno swojskości, polskości i tradycyi narodowej" 53 . Wydany ponad sto lat temu poradnik Iwanickiego nie stracił wiele na aktualności. W 2017 r. ukazał się reprint tej napisanej przystępnym językiem książki ${ }^{54}$. Ułatwiło to tym samym dostęp do zawartej w niej wiedzy, czerpiącej z najlepszych tradycji budowlanych.

Tadeusz Obmiński (1874-1932) był jednym z ostatnich profesorów architektury na PL, którzy studia ukończyli jeszcze w XIX w. (w 1898 r.). Zaliczany jest do grona czołowych lwowskich architektów pierwszego trzydziestolecia XX w. oraz uznawany za ,jednego z najwybitniejszych twórców architektonicznej panoramy nowoczesnego Lwowa" ${ }^{55}$. Obmiński był wieloletnim pracownikiem

${ }^{49}$ BPK, sygn. III-28117 (kolekcja: Druki polskie i obce wydane do 1918 r.).

${ }^{50}$ Album inżynierów i techników w Polsce, Lwów 1932, s. 10.

${ }^{51} \mathrm{~K}$. Iwanicki, Budownictwo wiejskie: poradnik przy wznoszeniu zabudowań na wsi, Kijów 1917, s. 1.

52 Ibidem.

${ }^{53}$ Ibidem, s. 176.

${ }^{54} \mathrm{~K}$. Iwanicki, Budownictwie wiejskie: poradnik przy wznoszeniu zabudowań na wsi, Szcze$\operatorname{cin} 2015$.

55 I. Żuk, Zakopiańszczyzna - secesja - neoklasycyzm: ewolucja stylowa w twórczości Tadeusza Obmińskiego, „Folia Historiae Artium. Seria Nowa”, t. 15, 2017, s. 97. 
naukowym tej uczelni. W ciągu niemal 25 lat swojej aktywności zawodowej na politechnice pełnił między innymi funkcję dziekana Wydziału Budownictwa Lądowego i Wydziału Architektonicznego oraz najważniejszą - rektora (na przełomie 1916 i 1917 r.). Był utalentowanym i wszechstronnym architektem, artysta, projektantem i dydaktykiem, który wykształcił liczne grono młodych architektów. Jest autorem kilkudziesięciu projektów, między innymi budynków użyteczności publicznej, kościołów, budynków mieszkalnych i przemysłowych. Znaczną ich część stanowią lwowskie realizacje - co przyniosło mu uznanie i pamięć współczesnych pokoleń. Poza budową nowoczesnego Lwowa jego uwagę skupiała przede wszystkim architektura cerkiewna oraz ludowe budownictwo drewniane. Aby poznać, zbadać i dokonać graficznego udokumentowania tych budowli, Obmiński odbył wiele wycieczek, głównie w rejonach Galicji Wschodniej. Pokłosiem tej pasji były rozprawy ogłaszane na łamach czasopism fachowych. W zbiorach BPK znajdziemy dwa tego typu opracowania: Fragmenty budownictwa drewnianego $w$ ziemi nowogrodzkiej ${ }^{56}$ oraz fundamentalną rozprawę $O$ cerkwiach drewnianych $w$ Galicyi ${ }^{57}$. Obmiński opisuje w nich budownictwo drewniane poprzez omówienie poszczególnych elementów konstrukcyjnych. Teksty są wzbogacone licznymi rysunkami wykonanymi przez autora, który posiadał doskonałe umiejętności artystyczne.

Jako ceniony specjalista i dydaktyk prowadził wykłady m.in. o materiałach budowlanych, kosztorysach i prowadzeniu budowy. W 1925 r. zostały one zebrane przez studentów Obmińskiego, a następnie wydane przez Związek Studentów Inżynierii PL w dwutomowym podręczniku Budownictwo ogólne (Lwów 1925) ${ }^{58}$. We wstępie wyjaśniono powody, dla których podjęto trud wydania tego skryptu:

Brak w literaturze technicznej polskiego podręcznika „Budownictwa ogólnego”, kłopoty kolegów, przygotowujących się do egzaminów z tego przedmiotu, oraz ogólny popyt na podobny podręcznik w szkołach i biurach technicznych poza naszą Uczelnią - oto powody, dla których Związek podjął prace około wydawnictwa tego skryptu ${ }^{59}$.

Tom pierwszy podręcznika obejmuje część teoretyczną i podzielony jest na cztery działy: Dział I. Elementy połączeń konstrukcyjnych; Dział II. Konstrukcje ograniczające przestrzeń z boku; Dział III. Konstrukcje ograniczające przestrzeń z góry; Dział IV. Urządzenia wewnętrzne. Tom drugi to atlas, w którym umieszczono rysunki reprodukowane w technice litografii - wykonali je „koledzy Düntuch, Gąsiorowski i Grott" ${ }^{60}$.

\footnotetext{
${ }^{56}$ BPK, sygn. J.IV.9.

${ }^{57}$ BPK, sygn. III-18969 (kolekcja: Cracoviana).

${ }^{58}$ BPK, sygn. III-17806, III-306357 (kolekcja: Lwowiana).

59 T. Obmiński, Budownictwo ogólne. 1, Tekst, Lwów 1925, s. V.

${ }^{60}$ Ibidem.
} 


\section{NOWE POKOLENIE ARCHITEKTÓW}

Z publikacji młodszego pokolenia absolwentów, a następnie profesorów Wydziału Architektonicznego PL, posiadamy opracowania autorstwa Mariana Osińskiego (1883-1974), który w latach 1901-1906 studiował na tym Wydziale. Do 1938 r. jego działalność naukowo-dydaktyczna była związana z lwowską politechnika, gdzie wykładał przedmioty: formy architektoniczne oraz perspektywa malarska, a w latach 1936-1938 pełnił funkcję dziekana Wydziału Architektonicznego. Po 1945 r. swoje życie prywatne oraz zawodowe związał z Gdańskiem i tamtejszą politechnika, gdzie zasłużył się również na polu odbudowy lokalnych zabytków zniszczonych podczas wojny. Osiński jest uznawany za twórcę gdańskiej szkoły architektonicznej. W zbiorach BPK znajduje się książka Osińskiego Zamek w Żótkwi (Lwów 1933) ${ }^{61}$, będąca zarazem podstawą uzyskania przez niego tytułu doktora ${ }^{62}$. Studium to jest szczegółową analizą formy architektonicznej zamku, jego detali i wyposażenia na przestrzeni wieków, wzbogacone zostało rycinami oraz fotografiami w większości autorstwa innego architekta, absolwenta PL, Feliksa Haczewskiego. Znajdziemy tu plany pięter oraz dokonaną przez Osińskiego rysunkową rekonstrukcję fasady zamku umieszczoną na czterech rozkładanych tablicach.

Jednym z najważniejszych polskich architektów pierwszej połowy XX w. był Adolf Szyszko-Bohusz (1883-1948). Jako student kształcił się na kilku europejskich uczelniach, natomiast z PL związany był od 1912 r., gdzie jako profesor nadzwyczajny rozpoczął pracę na Wydziale Architektonicznym. W $1916 \mathrm{r}$. został wskazany na kierownika prac konserwatorskich Zamku na Wawelu; w czasie prowadzonych tam działań dokonał kilku cennych odkryć archeologicznych. Jego współpraca z PL zakończyła się w 1920 r., kiedy przeniósł się do krakowskiej Akademii Sztuk Pięknych i objął kierownictwo Katedry Konserwacji Architektury Zabytkowej. Szyszko-Bohusz jest autorem licznych projektów, spośród których warto wymienić krakowskie realizacje: Dom Towarzystwa Ubezpieczeń „Feniks”, dom im. J. Piłsudskiego przy ul. Oleandry, krypty Juliusza Słowackiego i Józefa Piłsudskiego na Wawelu, Gimnazjum OO. Paulinów na Skałce w Krakowie czy Zamek Prezydenta RP w Wiśle. W twórczości piśmienniczej Szyszko-Bohusza można wyróżnić dwa etapy. Pierwszy związany był z działalnością rozpoczętą już w czasach studenckich i kontynuowaną w trakcie pracy na lwowskiej uczelni. Z tego okresu pochodzi seria rozpraw publikowanych na łamach „Sprawozdań Komisyi do Badania Historyi Sztuki w Polsce”. Jest on autorem bądź współautorem prac dotyczących najstarszych zabytków architektury

${ }^{61}$ BPK, sygn. II-22122 (kolekcja: Lwowiana).

${ }^{62}$ Strona redakcyjna: „Praca przyjęta jako rozprawa przez Radę Wydziału Architektonicznego Politechniki Lwowskiej w dniu 16 stycznia 1933 r., na wniosek referenta Dr. Oskara Sosnowskiego, Prof. Politechniki Warszawskiej, i korreferenta Inż. Witolda Minkiewicza, Prof. Politechniki Lwowskiej". 
polskiej, głównie gotyckich kościołów i zamków. Artykuły te są rezultatem wnikliwych badań i prac inwentaryzacyjnych prowadzonych podczas licznych wyjazdów naukowych na tereny Królestwa Polskiego i Litwy, w których uczestniczył już jako student, mając poparcie Komisji Historii Sztuki Akademii Umiejętności w Krakowie. W zbiorach BPK znajdziemy cztery prace z tego okresu: Kościoły polskie dwunawowe. Zabytki w nich ocalate czy też pośrednio z nimi wiqżace i król Kazimierz Wielki - wspólnie z M. Sokołowskim (Kraków 1907); Beszowa, Skalbmierz i system krakowski. Bodzentyn (Kraków 1913); Dwa kościoły jednonawowe: Krzcięcice i Potok Wielki (Kraków 1913); Trzy kościoty halowe: Olkusz, Kraśnik, Kleczków - wspólnie z M. Sokołowskim (Kraków $1913)^{63}$. O rozprawach tych pisano, że ,są zwięzłe, rzeczowe, dobrze zaznajamiają czytelnika z postacią opisywanych zabytków" ${ }^{64}$. Wszystkie opracowania są wzbogacone bogatym materiałem pomiarowym oraz ilustracyjnym w postaci rysunków i fotografii. Autorem rysunków i pomiarów jest Szyszko-Bohusz, natomiast fotografie w większości wykonał Stefan Zaborowski ${ }^{65}$. Oprócz tych obiektów Szyszko-Bohusz inwentaryzował również zabytki architektury żydowskiej. Jego praca Materjały do architektury bożnic w Polsce (Kraków 1927) ${ }^{66}$, która powstała na podstawie materiałów zgromadzonych podczas wycieczek, była pionierską $\mathrm{z}$ tego zakresu. Był on jednym z nielicznych wówczas badaczy (obok m.in. Władysława Łuszczkiewicza, Zygmunta Glogera czy Władysława Matlakowskiego) zajmujących się żydowskimi domami modlitwy ${ }^{67}$. Opisując je, przyczynił się do zachowania pamięci o obiektach, które do naszych czasów nie przetrwały (np. synagogi w Wyszogrodzie czy w Przedborzu).

Drugi etap jego twórczości naukowo-piśmienniczej rozpoczyna się w momencie podjęcia przez niego prac restauracyjnych na Wawelu. Szyszko-Bohusz zasłynął jako osoba, która miała

[...] duże uzdolnienie do badania starych murów, umiał w nich czytać i miał szczęśliwą rękę, toteż odkrył przedromańską tetrakonchę śś. Feliksa i Adaukta w murach dawnych kuchen królewskich, oraz pod północną częścią zachodniego skrzydła zamku wschodnią część (prezbiterium i transept) bazyliki typu saskiego, którą w ślad za jego interpretacją uznać należy za romańską katedrę z czasów Bolesława Chrobrego ${ }^{68}$.

${ }^{63}$ BPK, sygn. III-18969 (kolekcja: Cracoviana).

${ }^{64}$ A. Bochnak, Ś. p. Adolf Szyszko-Bohusz (1883-1948), „,Rocznik Towarzystwa Naukowego Warszawskiego", t. 41, 1948, s. 173.

${ }^{65}$ Stefan Wojciech Zaborowski (czynny zawodowo w latach 1905-1916) - fotograf Komisji Historii Sztuki AU. Zob. W. Walanus, Z dziejów fotograficznej dokumentacji polskiego dziedzictwa kulturowego: kampanie inwentaryzacyjne Adolfa Szyszko-Bohusza i Stefana Zaborowskiego, „Folia Historiae Artium. Seria Nowa”, t. 14, 2016, s. 59-89.

${ }^{66}$ BPK, sygn. III-15018 (kolekcja: Cracoviana).

${ }^{67}$ E. Bergman, Synagogi i cmentarze żydowskie na Mazowszu, „Rocznik Mazowiecki”, t. 25, 2013, s. 76.

${ }^{68}$ A. Bochnak, op. cit., s. 173. 
Rezultatem prowadzonych prac są między innymi trzy rozprawy: Rotunda świętych Feliksa i Adaukta (N.P. Maryi) na Wawelu (Kraków 1918) ${ }^{69}$; Wawel średniowieczny (Kraków 1932) ${ }^{70}$; Studia nad Katedra Wawelska (Kraków $1946)^{71}$. Wszystkie te prace opatrzone są rysunkami i planami wykonanymi przez Szyszko-Bohusza. Jego dokonania na tym polu trafnie ocenił Adam Bochnak: „Badaniami nad naszą architekturą średniowieczną, zwłaszcza nad problemami przedromańskiego i romańskiego Wawelu, tak wybitnie wzbogacającymi obraz początków architektury w Polsce, Szyszko-Bohusz dobrze się zasłużył nauce polskiej" 72 .

Szyszko-Bohusz brał również udział w powstaniu niemieckojęzycznego przewodnika autorstwa Józefa Piotrowskiego Lemberg: und Umgebung (Żótkiew, Podhorce, Brzeżany und and.): Handbuch für Kunstliebhaber und Reisende: 130 Abbildungen am Stadplan: d. innere Stadt, alph. Verzeichnis d. Strassen, Plätze u. Gärten, d. Kirchen u. öffentl. Bauten, d. Routen d. elektr. Str.-Bahn (Lemberg 1917) ${ }^{73}$. Jest to ostatni wydany w okresie zaboru austriackiego przewodnik po Lwowie i jego okolicach ${ }^{74}$. Publikacja w znacznej części poświęcona jest historii sztuki lwowskiej oraz najważniejszym zabytkom wielokulturowego miasta. Szyszko-Bohusz opatrzył przewodnik krótkim wstępem, był ponadto autorem okładki w stylu secesyjnym. W centralnym miejscu grafiki znajduje się wytłaczany złotymi literami napis Lwów, a pod nim herb miasta Lwowa, całość na tle herbu Rzeczypospolitej Obojga Narodów. Opracowanie wzbogacone jest 130 ilustracjami oraz dwustronną rozkładaną mapą Lwowa wraz z planem śródmieścia.

Feliks Markowski (1902-1985) był architektem oraz wykładowcą akademickim. W 1924 r. rozpoczął studia na PL, gdzie cztery lata później uzyskał tytuł inżyniera architekta. Następnie w 1935 r. przedstawił pracę Polskie dwory zwyczajne i obronne, na podstawie której otrzymał tytuł doktora nauk technicznych. Do 1944 r. pracował na PL w Katedrze Architektury ${ }^{75}$. W tym czasie jego główne zainteresowania badawcze obejmują architekturę zamków i pałaców rozpatrywaną pod kątem historycznym. Od 1945 r. był związany z Politechniką Gdańską, gdzie brał czynny udział w tworzeniu Katedry Architektury i Planowania Wsi na Wydziale Architektury. Profesor Markowski był autorytetem przede wszystkim w zakresie budownictwa drewnianego, ponadto był entuzjastą sztuki i kultury

${ }^{69}$ BPK, sygn. III-33116 (kolekcja: Cracoviana).

${ }^{70}$ BPK, sygn. III-33025 (kolekcja: Cracoviana).

${ }^{71}$ BPK, sygn. III-34251 (kolekcja: Cracoviana).

72 A. Bochnak, op. cit., s. 173.

73 BPK, sygn. I-25112 (kolekcja: Lwowiana).

74 J. Smirnow, O przewodnikach po Lwowie. Część 1, „Kurier Galicyjski” 2014, nr 20 (216), s. 26.

75 Dokładny wykaz katedr, gdzie pracował Feliks Markowski, można znaleźć w opracowaniu Zbysława Popławskiego. Zob. Z. Popławski, Politechnika Lwowska w latach 1844-1945: rodowody katedr, wykaz nauczycieli akademickich, dziedzictwo, Kraków 1999, s. 170. 
ludowej. Opracowanie Polskie dwory zwyczajne i obronne XVI-XIX w. (Lwów $1935)^{76}$, będące - jak sam napisał w nocie odautorskiej - kompilacją rozprawy doktorskiej, jest „Związłem streszczeniem obszerniejszej pracy, która przygotowana do druku, wraz z licznemi rysunkami, pomiarami i fotografjami, z powodu panujących obecnie warunków ekonomicznych nie może być na razie wydana w całości" ${ }^{77}$. Rysunki umieszczone w tekście również zostały wykonane przez Markowskiego. To, co znacznie podnosi wartość posiadanego w zbiorach BPK egzemplarza, to umieszczona na nim odręczna dedykacja autora: „JW Panu Inż.-arch. J. Różyckiemu w koleżeńskim upominku autor. 5.VI.937"78.

Obok architektów, którzy zajmowali się, upraszczając, projektowaniem budynków, byli również ci, których uwaga skupiała się na szeroko pojętych zagadnieniach dotyczących planowania przestrzeni miejskich. Osobno zostaną więc omówione prace dwóch architektów urbanistów z początku XX w., wychowanków PL. Jako że okres ich działalności przypadł na czasy wojenne i swoją uwagę kierowali przede wszystkim na odbudowę zniszczonych zespołów miejskich, można ich nazwać „lekarzami miast”. Podejmowali oni w swoich publikacjach kwestie związane z najpilniejszymi problemami tego okresu i byli przedstawicielami lwowskiej szkoły urbanistycznej. Początki zainteresowania problematyką regulacji miast i racjonalnej ich zabudowy sięgają końca XIX w.; były to głównie artykuły publikowane na łamach „Czasopisma Technicznego” czy kwestie poruszane między innymi na czterech kolejnych Zjazdach Techników Polskich ${ }^{79}$. Zauważono również potrzebę wprowadzenia do programu nauczania na lwowskiej politechnice przedmiotu: budowa miast ${ }^{80}$. Główny asumpt do uporządkowania przestrzeni miast stanowiły skutki I wojny światowej, co podkreślał Roman Feliński: „Odbudowa zniszczonego kraju będzie przez cały dziesiątek lat naszą najgłówniejszą pracą, w której odbudowa budynkowa obejmować będzie jedną z najpoważniejszych jej części”"81.

Działało wówczas liczne grono - wywodzących się między innymi z PL specjalistów, którzy podjęli się tego wyzwania. Wśród nich warto dostrzec postać Ignacego Drexlera (1878-1930). Był on lwowskim inżynierem architektem i urbanista, profesorem nadzwyczajnym PL oraz krytykiem sztuki i esteta. Studia na Wydziale Inżynierii Lądowej PL odbył w latach 1897-1903. Następnie w okresie 1913-1925 prowadził wykłady zlecone z budowy miast. Jesienią 1926 r. został mianowany profesorem nadzwyczajnym nowo powstałej, pierwszej w Polsce, Katedry Budowy Miast na Wydziale Inżynierii Lądowej i Wodnej.

\footnotetext{
${ }^{76}$ BPK, sygn. II-325244 (kolekcja: Lwowiana).

${ }^{77}$ F. Markowski, Polskie dwory zwyczajne i obronne XVI-XIX w., Lwów 1935, s. [4].

78 Prawdopodobnie chodzi o inżyniera budownictwa Jana Różyckiego (1901-1991).

79 Zjazdy Techników Polskich: III (1894), IV (1899), V (1910) oraz VI (1912).

${ }^{80}$ J. Lewicki, Roman Feliński: architekt $i$ urbanista: pionier nowoczesnej architektury, War-

${ }^{81}$ R. Feliński, Budowa miast, Lwów 1916, s. 2.
} szawa 2007, s. 110. 
W roku akademickim 1928/1929 był dziekanem tegoż Wydziału. Jako teoretyk i praktyk planowania miast miał wpływ na kształtowanie urbanistyki w Polsce. Pozostawił liczne publikacje naukowe, a w zbiorach BPK znajduje się między innymi odbitka z "Czasopisma Technicznego” Konkursowego planu regulacyi Wielkiego Krakowa (Lwów 1911) ${ }^{82}$. Drexler wykonał projekt regulacyjny dla Krakowa na konkurs, który rozpisano w 1910 r. Jego praca nie zdobyła żadnej z trzech głównych nagród, ale mimo to została zakupiona przez Gminę Miasta Kraków oraz opublikowana na łamach „Czasopisma Technicznego”. Drexler w opisie projektu, który zatytułował „Słowacki w kole zielonem”, napisał: „W przedłożonym projekcie starałem się zgodnie z zasadami, wymienionemi w programie, dać podstawy pod rozwój Wielkiego, a przede wszystkiem zdrowego, wygodnego i pięknego Krakowa" ${ }^{83}$. Kolejna praca Drexlera to Odbudowanie wsi i miast na ziemi naszej: rycin sto (Lwów 1921) ${ }^{84}$, będąca drugim wydaniem poczytnego opracowania, którego

w niespełna rok od chwili pierwszego wydrukowania niniejszej książki, wyczerpał się zupełnie wcale spory jej nakład. Trudne jednak warunki wydawnicze, a przede wszystkiem nieobycie się z szybko rosnącą drożyzną papieru i druku, wywołały zwłokę ponownej edycji ${ }^{85}$.

Praca ta była zgłoszona w konkursie im. barona Romana Gostkowskiego na studium z zakresu odbudowy miast, gdzie przyznano jej drugie miejsce i została uznana za niezwykle wartościową. W recenzji zamieszczonej w „Architekcie” (1922) możemy przeczytać, że autor

[...] stara się wszystkimi, na jakie go stać, środkami dowieść w systematycznie ułożonych rozdziałach na czem polega piękno zespołu budynków i ulic w otoczeniu przyrody. Trwała wartością książki pozostanie gorące umiłowanie przedmiotu, które udziela się czytelnikowi, kierując jego uwagę przez liczny dobór ilustracji osad polskich na grunt rodzimy. Ma to znaczenie nie tylko dla nas, ale dla powszechnej nauki o budowie miast ${ }^{86}$.

W opracowaniu Szerokość jezdni w ulicach miejskich (Lwów 1928) 87 $^{87}$ Drexler potwierdził swoje najwcześniejsze postulaty odnoszące się do zmiany sieci ulicznej Lwowa, wytyczenia nowych ulic i głównych szlaków komunikacyjnych. W rozważaniach jako przykład posłużyły mu śródmiejskie ulice oraz place Lwowa.

Jednym z najważniejszych polskich urbanistów pierwszej połowy XX w. był Roman Feliński (1886-1953). Studia na PL rozpoczął w 1903 r. na Wydziale Budownictwa Lądowego. Po dwóch latach wyjechał na dalsze studia do Monachium, gdzie w 1908 r. uzyskał tytuł inżyniera architekta. Po powrocie

\footnotetext{
${ }^{82}$ BPK, sygn. III-33841 (kolekcja: Lwowiana).

${ }^{83}$ I. Drexler, Konkursowy plan regulacyi Wielkiego Krakowa, Lwów 1911, s. 5.

${ }^{84}$ BPK, sygn. II-1136 (kolekcja: Lwowiana).

${ }^{85}$ I. Drexler, Odbudowanie wsi i miast na ziemi naszej: rycin sto, Lwów 1921, s. I.

${ }^{86}$ Rec.: W. Krzyżanowski, Piśmiennictwo, „Architekt”, R. 17: 1922, z. 3-4, s. 36.

${ }^{87}$ BPK, sygn. II-24835 (kolekcja: Lwowiana).
} 
do Lwowa podjął kolejno pracę w dwóch większych biurach architektoniczno-budowlanych. W 1919 r. przeniósł się do Warszawy, gdzie w latach 1926-1944 kierował własnym biurem architektoniczno-urbanistycznym. Prowadził również ożywioną działalność naukowo-publicystyczna. Był autorem kilku referatów dotyczących problematyki odbudowy kraju, które były później publikowane w „Czasopiśmie Technicznym”. Książka Felińskiego Budowa miast z ilustracyami i planami miast (Lwów 1916) ${ }^{88}$ była pierwszym polskim opracowaniem z zakresu historii budowy miast, co sam autor podkreślił we wstępie: „Niniejsza praca jest pierwszą dotychczas próbą sformułowania zasad i wyników wiedzy budowy miast, oraz przedstawienia ze stanowiska tej wiedzy naszych zadań przy odbudowie naszych miast i miasteczek" ${ }^{\prime 89}$. Publikacja podzielona jest na dziesięć rozdziałów, w których Feliński porusza między innymi takie zagadnienia, jak: rozwój miast $\mathrm{i}$ ich budowa w dawnych wiekach, problemy komunikacyjne, kwestie higieny miasta i środowiska mieszkaniowego, a co za tym idzie - wartości ogrodów i terenów zielonych. Na zakończenie zwraca uwagę na istotne znaczenie ustawodawstwa budowlanego w kształtowaniu budynków i miast, podkreślając również konieczność jego uaktualnienia: ,[... [ nasze dotychczasowe ustawy budowlane są w przeważnej swej części przestarzałe i wymagają gruntownej zmiany" ${ }^{\prime 90}$. Monografia uzupełniona jest licznymi planami miast i fotografiami, a odwołania Felińskiego do ówczesnych zagranicznych autorów świadczą o jego dobrej znajomości piśmiennictwa z zakresu urbanistyki. Drugim opracowaniem Felińskiego była Kwestja mieszkaniowa przyszłości a siedziby $i$ byt inwalidów wojennych (Warszawa 1919) ${ }^{91}$. Już przed jej wydaniem Feliński dostrzegł problem osób poszkodowanych w wyniku wojny i publikował w prasie oraz czasopismach szereg rozpraw dotyczących ich problemów mieszkaniowych. Jednocześnie pracował nad wspomnianą książką, która została ostatecznie wydana w 1919 r., i - jak sam napisał - ,poświęcona przede wszystkiem naszym inwalidom, wdowom i sierotom polskim pragnie być skromną pomocą w ukształtowaniu tych doniosłych spraw"92. Najważniejszym dziełem w dorobku tego urbanisty są Miasta, wsie, uzdrowiska w osiedleńczej organizacji kraju (Warszawa 1919) ${ }^{93}$. Książka, będąca podsumowaniem poglądów Felińskiego na kwestię zagadnień urbanistycznych i planowania przestrzennego miast, oparta została głównie na doświadczeniach autora i jego licznych artykułach. W recenzji tej pracy można przeczytać:

\footnotetext{
${ }^{88}$ BPK, sygn. II-1497, II-6397 (kolekcja: Lwowiana).

${ }^{89}$ R. Feliński, op. cit., s. 2.

${ }^{90}$ Ibidem, s. 106.

${ }^{91}$ BPK, sygn. II-6313 (kolekcja: Druki polskie wydane między 1918-1945 r.).

${ }_{22}$ R. Feliński, Kwestja mieszkaniowa przyszłości a siedziby i byt inwalidów wojennych, War-

${ }^{93}$ BPK, sygn. II-328939 (kolekcja: Druki polskie wydane między 1918-1945 r.).
} szawa 1919, s. XII. 
[...] napisana z pasją - będąca niewątpliwym wyrazem umiłowania zawodu urbanisty - zawodu stanowiącego treść życia autora [...]. Świetnie dobrane, piękne fotografie zaopatrzone w dobrze zredagowane podpisy, ułatwiają zrozumienie poglądów autora, których praktyczną ilustrację stanowią liczne reprodukcje projektów własnych lub wykonanych pod jego kierunkiem. Książkę czyta się z łatwością i korzyścią ${ }^{94}$.

Z omawianych przykładów wynika, że dorobek piśmienniczy architektów, których losy były ściśle związane z PL, był przede wszystkim egzemplifikacją ich poglądów artystycznych. Ponadto autorzy dostrzegali wartość i szlachetność rzemiosła rodzimego, tym samym stając się piewcami i orędownikami tak zwanego stylu narodowego. Na uwagę zasługuje również fakt, że część z przytoczonych prac stała się także uzupełnieniem ówczesnych programów nauczania i pomimo upływu lat nie straciła na wartości - do dzisiaj są one wydawane w formie reprintów.

Pomimo upływu 126 lat od momentu powołania samodzielnego Wydziału Architektonicznego Politechniki Lwowskiej, jego kadra i wychowankowie wciąż wyzwalają zainteresowania naukowo-badawcze, związane z ich wybitnymi osiągnięciami na polu architektoniczno-urbanistycznym. To właśnie najwcześniejsze pokolenie lwowskich architektów dokonało licznych pionierskich prac inwentaryzacji zabytków naszej kultury, wprowadziło nowe kierunki teoretyczne, style, a przede wszystkim wychowało grono przyszłych adeptów tego zawodu. Prace projektowe i teoretyczne stanowią trwałe świadectwo osiągnięć architektów oraz pozostają ważnym elementem w historii architektury polskiej. Po dziś dzień są nieprzerwanym źródłem inspiracji dla młodych pokoleń architektów.

Biblioteka Politechniki Krakowskiej poprzez nieustannie podejmowane działania, mające na celu ochronę i upowszechnianie zachowanej spuścizny, przyczynia się do pielęgnowania tradycji lwowskiej uczelni, w tym jej osiagnięć na polu architektury. Dzięki temu, że Biblioteka sukcesywnie digitalizuje i udostępnia cyfrowe wersje najstarszego księgozbioru, możliwe jest zapoznanie się z dokonaniami minionych pokoleń oraz czerpanie inspiracji i wiedzy z najlepszych wzorców.

${ }_{94}$ R. Feliński, Miasta, wsie, uzdrowiska w osiedleńczej organizacji kraju, Warszawa 1919. Rec.: J.G., Z ksiażek $i$ wydawnictw, „Dom, Osiedle, Mieszkanie”, R. 7: 1935, z. 10, s. 33. 
AGNIESZKA GÓRSKA, ANNA KRAUS

\author{
SELECTED LITERATURE OF ARCHITECTS RELATED \\ TO THE LVIV UNIVERSITY OF TECHNOLOGY. \\ A STUDY ON THE BASIS OF RESEARCH FROM THE COLLECTIONS \\ OF THE CRACOW UNIVERSITY OF TECHNOLOGY LIBRARY BEFORE 1945
}

Keywords: architects, architectural literature, Lviv Polytechnic, book collection of The Cracow University of Technology Library, 19th/20th century

\title{
SUMMARY
}

The purpose of this publication is to draw attention to the scientific and historical value of the literary achievements of architects associated with The Lviv University of Technology on the basis of copies held in the collections of The Cracow University of Technology Library. Due to the extensive source material, the works of eleven selected architects were discussed. The characterization will take the form of library resources analysis, supported by source research. The study focuses solely on pre-1945 collections. The most interesting publications will be discussed in terms of their historical and substantive value.

\section{АГНЕШКА ГУРСКА, АННА КРАУС}

\section{ИЗБРАННЫЕ ПЕЧАТНЫЕ РАБОТЫ АРХИТЕКТОРОВ, СВЯЗАННЫХ СО ЛЬВОВСКОЙ ПОЛИТЕХНИКОЙ. ИССЛЕДОВАНИЕ НА БАЗЕ ФОНДОВ БИБЛИОТЕКИ КРАКОВСКОЙ ПОЛИТЕХНИКИ ДО 1945 ГОДА}

Ключевые слова: архитекторы, печатные работы по архитектуре, Львовская политехника, книжное собрание библиотеки Краковской политехники, XIX/XX век

\section{АННОТАЦИЯ}

Цель данной работы - привлечь внимание к научной и исторической ценности печатных работ архитекторов, связанных с Львовской политехникой. Анализ основан на публикациях из фондов библиотеки Краковской политехники. Принимая во внимание обширную базу источников, анализом охвачены работы одиннадцати избранных архитекторов. Характеристика будет представлена в виде анализа библиотечного собрания, дополнена исследованиями источников. Исследование сосредоточено только на печатной продукции, опубликованной до 1945 года. 